\title{
University Staff's Perception of Deregulation on Higher Education in Nigeria
}

\author{
Adebayo, Florence Aduke \\ Faculty of Education, \\ Ekiti State University, Ado-Ekiti \\ Ekiti State, Nigeria \\ E-mail: dukesseyi@yahoo.com
}

Received: 16-02- 2013

doi:10.7575/aiac.ijels.v.2n.2p.63
Accepted: 29-03-2013

URL: http://dx.doi.org/10.7575/aiac.ijels.v.2n.2p.63
Published: $30-04-2014$

\begin{abstract}
The study investigated the university staff's perception on deregulation of higher education in Nigeria. Descriptive research of the survey type was used for the study. The population comprised all the university staff of universities in Ekiti and Ondo states, Nigeria. Simple random sampling technique was used to select 700 academic and non-academic staff from the Federal and State universities in Ekiti and Ondo states. Research instrument designated University Staff Perception of Deregulation on Higher Education (USPDHE) was used in collecting data. The questionnaire was subjected to face and content validity. The reliability co-efficient of the instrument was 0.75 . The results showed that deregulation improved academic standard of the universities except in the areas of curriculum innovation and collaborative research and does not guarantee job security nor improve staff development and equity in salary structure but it contributed to managerial effectiveness, efficiency and accountability, It also showed that students were affected in the area of access to higher education, class structure, admission choice and exploitation by the institutions. It equally showed that deregulation is not improving the funding of higher institutions in Nigeria instead it throws the institution into dilemma of sourcing for fund. Some of the recommendations are: using management strategies at the institutional level, autonomy should use management strategies that emphasize improved standards in terms of improved curricula, and academic excellence by all and sundry within the system. Also, to have the full gains of deregulation, climate of academic integrity should be enshrined in the operation of the university system.
\end{abstract}

Keywords: deregulation, university staff, student access, funding, academic standard

\section{Introduction}

The concept of deregulation has to do with partial or full withdrawal of rules and regulations and control from a business venture or organization so that such organization can make its own rules and regulation for efficient and effective operation determine by the market forces. Nigeria, like other parts of the globe, has witnessed the deregulation of the higher education, down-stream oil sector, telecommunication, airlines, banking sector, and recently the Power Holding Company. Also, deregulation implies the removal of governmental interference over the running of a system in order for the system to decide its optimum level of operation through the forces of the market.

Deregulation as applicable to education means government divesting its interest in it and encouraging private sector participation in the management of the educational system for effective achievement of the objectives and goals of education. Deregulation has manifested in increasing springing up of fee-paying private primary, secondary and higher Schools. These private Schools assist in ensuring that parents of children for these levels have better opportunities to choose their children's schools based on some factors bordering on financial capabilities.

At the university level, deregulation has been linked with privatization or university autonomy where the university will be self-regulated and controlled. In effect, the university has the sole responsibility of determining its operations in terms of intakes, financing and other important decisions relevant to its operation. Among the manifestations of university deregulation is the establishment of private universities and increased fees and levies. It becomes imperative to stress that deregulation policies on Nigerian university education should not primarily emphasize less funding and more fees. Other requirement for effective deregulation is strategic planning at the institutional level, accountability, proper management, functional communications system and academic integrity. With the advents of civilian rule in 1979, religious organizations and individuals were allowed to own schools without subvention from the government. Contemporary times have witnessed proliferation of private schools that charge exorbitant fees. Only wealthy Nigeria's could afford to educate their children in the schools. The poor ones cannot afford the cost of education. Most of their private community and voluntary agency schools were indeed famous, competing favorably with the few government schools at that time. With the take-over of these schools, Nigeria's education system became centralized and characterized with unnecessary bureaucracy. The "complete and dynamic intervention" declared by government in the National policy on Education (1977), revised in 1981, 1998 and 2004 has turned out to be an albatross in the country’s 
education system. Today, the system is characterized overcrowded student hostel classrooms without lockers and seats for children, departmental offices that are ill-equipped, lawns overgrown with weeds and shrubs, hostels and faculty building without toilet facilities and absence of meaningful staff development programme (Ejiogu, 2003).

With this depicted scenery of the country's education system, it was no longer worthwhile for the government to be involved in all the tiers of nation's education system as government alone could no longer bear the burden of providing education for its citizen. If education is to be meaningful and relevant, there must be a relaxation or dismantle of legal and governmental restrictions on the operations of education business in the country. This was what led to deregulation in the sector in order to enhance efficiency. Upon this backdrop this paper examined the university staff perception of deregulation on higher education in Nigeria.

\section{Statement of the Problem}

Education in Nigeria today seems to face with the challenges of gross under funding, shortage of qualified manpower, inadequate facilities and equipment and bloated student population. A visit to public educational institutions in the country will reveal the sorry state of the education sector. The decay in the sector is not unconnected with government's centralization of this sector. With a population of about 126 million, spread among more than one hundred heterogeneous ethnic groups, Nigeria can only ill-afford a centralized education system in which pretends to be the sole provider. Now the government claims that it is no longer buoyant as it used to be, it has tactfully shun its sole provident position leaving educational institution as orphans, urging them to look for alternative sources of financing their programmes. Furthermore, the heterogeneous nature of the Nigerian society does not favour centralization of the education system. Being culture-bound, education promotes the cultural heritage of the people. A deregulated education system will help pressure the heterogeneity of any country (Adeogun, Subairu \& Osifila, 2009).

If Nigeria education system continues to depend on government for its funding, then, it may be difficult for the system to reach its take off-point. Therefore, the most desired goal of sustainable quantitative and qualitative educational development will continue to be together.

It is against this backdrop that the study would find answers to these following questions:

1. What is the impact of deregulation on the academic standard of higher institutions in Ekiti and Ondo states, Nigeria?

2. What is the impact of deregulation of higher institutions on the university staff?

3. What is the impact of deregulation of higher institutions on the students?

4. What is the impact of deregulation on funding of higher institutions in Ekiti and Ondo states, Nigeria?

\section{Purpose of the Study}

The purpose of this study is to examine the perception of University Staff on the impact of deregulation on academic standard, institutional staff, students and funding of higher institutions in Ekiti and Ondo states, Nigeria.

\subsection{Historic Perspective of the Global Practices of Deregulation of Higher Education}

Initiative for deregulation of education has been taken by developed and developing countries of the world. The rapid growth of the non-government sector of higher education, after over years of repression of all private initiative in education, has given for Poland the label of "a Little America in the Heart of Europe". While the greatest innovation clearly taking place in the private sector, the state sector, has been dramatically affected by the liberalization of the political system and the market economy. There is little doubt that competition from the private sector has also played a significant part in stimulating the state sector. The latter did not respond through fees being imposed on selected groups, particularly part-time, evening classes and correspondence students. The difference in the academic standards achieved by full-time, as opposed to part-time or external students are very significant, especially in the case of the nongovernment sector (Adeogun, Subair \& Osifila 2009).

By 1980, in the United States the government discovered that regulation was becoming stifling. The main focus of education deregulation is in the area of parental freedom to control their children's schooling. The most obvious example of deregulation is that of School voucher programmes. Voucher programmes distribute public money earmarked for education directly to individual parents to help them send their children to the parochial or secular private schools of their choice. Another example of education deregulation is home schooling which eliminates virtually all government involvement in education thereby, greatly increasing parental autonomy (Denise, 2002).

In Britain, too, deregulation has brought about autonomous schools, with greater responsibility placed on the schools to determine their own destinies. A very important factor that occurs in deregulation exercise is fund higher bills. In education, tuition deregulation is the usual focus, and the resultant high fees have always been met by parents (Tony, 2009). Therefore, Nigeria is no exception of the deregulation of higher education trend.

\subsection{Deregulation of Higher Education}

\subsubsection{Implications on students:}

Deregulation of any sectors of the economy implies fewer subsidies on those sectors by the government. Deregulation, if properly planned and operated, may result in more access to the services provided. Access to education is the opportunity to participate in the education sector. It is generally seen from the perspective of the number of person enrolled in the education system as compared with those who should have been accommodated in the system but are not. Many Nigerian parents and students do experience a lot of anxiety and trauma every year, in search of admission 
into the universities. As reported by Salim (2004), the Joint Admissions and Matriculation Board (JAMB) has been recording a steady astronomical rise of application forms, without a corresponding increase either in the number of universities or in the absorptive capacities of the existing universities. Deregulated education could lead to less access, if the effects of increased fees and levies are not cushioned (Castelan, 2004).

As reported by Canadian Federation of Students (2003), due to deregulation, access to higher education has been severely compromised and student debt has sky-rocketed. Hence, increasing fees and levies without any form of assistance to the low-income group would further reduce access to university education. However, government involvement in the establishment of more universities, expanding the facilities of the existing ones, allowing establishment of more private Universities that are of high standards and giving more financial support to the children low-income earners could be a way out (Aina, 2013).

\subsection{Funding}

Higher Education is capital-intensive. This is consequent on specialized courses mounted and tailored towards man power development for the different sectors of the economy. Poor funding has been a major setback to the development of university education in Nigeria (Uvah, 2003) Nigerian government has been the major financier of higher education until recently when some private universities were established. Federal government budgetary allocations are being supplemented by charges and levies paid by students and supported by national and international bodies (Ukeje, 2002). Hence this study is conducted to access the impact of deregulation on funding of the higher institutions in Ekiti and Ondo States.

\subsection{Academic excellence}

In developed countries of the world, in addition to tuition, deregulation programme are focused on improved standards. In the U.S, schools that get waivers to mount some programmes must prove to be accountable, manifest in evidences of improvement on student's performance (Denis2002). The Nigerian universities are beginning to look in the direction of excellence with reviews of curricula and re-examination of vision and mission. The National Universities Commission has also initiated a compulsory accreditation of universities courses in Nigeria. One of the challenges posed by excellence to university administration is the need to ensure that staff and students understand their roles, duties, limitations, privileges and expectations of the universities under an environment of academic integrity. This would ensure a healthy academic environment for the achievement of personal and organizational goals. Furthermore, it might result in a healthy competition for excellence among the universities in order to attract the best among the candidates from the general pool.

\subsection{Remuneration and Conditions of Service}

Although in recent times in Nigeria the government adjusted the salary structure of the tertiary institutions to encourage the staff, it is alleged that the unfavorable remuneration packages are responsible for the migration of Nigerian academics and other professionals to other countries, notably South Africa, Botswana, Saudi Arabia and the United State of America. Hence, the reforms on education gave birth to higher and fairer wages for teaching staff and other staff and decentralization and deregulation of the system to minimize brain drain. This, in turn, could lead to more localization of trade union concerns and consequently to less instability in the system.

\subsection{University Staff Development}

Academic staff are required as part of their contract to carry research and to publish results of such research as a precondition for career development. Equally, those who are in the administration of the institutions are expected to upgrade themselves through seminars and induction course to avoid creating digital divide among staff. It seems difficult to pursue this development process in the face of poor funding and even poorer management of research funds by the universities, and in the face of inadequate research infrastructures in the universities and an almost total lack of interest on the part of the local private sector in sponsoring or utilizing the results of university research, only basic research of the publish-or-perish type tends to be carried out.

\section{Research Method}

Descriptive research of the survey type was used for the study. The population comprised all the university staff of Universities in Ekiti and Ondo states, Nigeria. Simple random sampling technique was used to select 700 academic and non-academic staff from the Federal and State Universities in Ekiti and Ondo states. Research instrument designated University Staff Perception of Deregulation on Higher Education (USPDHE) was used in collecting data on the basis of the research questions raised for this study.

The questionnaire were subjected to face and content validity by experts who matched all the items in the questionnaire with the research questions to ascertain whether the instrument actually measures what it was supposed to measure the reliability of the instrument was determined by conducting a split half reliability test in which, only one test is administered to eliminate measurement errors such as differences in testing conditions. The data of the two scores were correlated by employing the spearman Brown prophecy formula to estimate the reliability of the instrument which yielded 0.75 reliability co-efficient. This shown that the reliability co-efficient has a high internal consistency. The researchers with the help of the research assistants administered the questionnaire. Data collected were analyzed using percentages. 


\section{Results and Discussions}

Question 1: What are the impacts of deregulation on academic standard of higher institutions in Ekiti and Ondo states?

Table 1. Impact of deregulation on academic standard of higher institution

\begin{tabular}{|c|c|c|c|c|c|}
\hline$S / N$ & Deregulation of higher institutions leads to: & $\begin{array}{l}\text { Agree } \\
\text { Frequency }\end{array}$ & $\%$ & $\begin{array}{l}\text { Disagree } \\
\text { Frequency }\end{array}$ & $\%$ \\
\hline 1. & Curriculum innovation. & 80 & 11 & 620 & 89 \\
\hline 2. & Collaborative Research. & 48 & 7 & 652 & 93 \\
\hline 3. & Healthy competition for academic excellence. & 607 & 87 & 93 & 13 \\
\hline 4. & $\begin{array}{l}\text { Variation in the formulation and } \\
\text { implementation of policies. }\end{array}$ & 665 & 95 & 35 & 5 \\
\hline 5. & Effective supervision. & 595 & 85 & 105 & 15 \\
\hline 6. & Competitive market. & 363 & 52 & 337 & 48 \\
\hline 7. & Institutional autonomy. & 685 & 98 & 15 & 2 \\
\hline 8. & Active private participation. & 647 & 92 & 53 & 8 \\
\hline
\end{tabular}

Table 1 shows that deregulation improved academic standard of the universities except in the areas of curriculum innovation and collaborative research. The study of Aladetoyinbo and Adeniyi (2012) supported this finding when it reinstated that in Nigeria, research had the lowest percentage of Gross National Product.

Research Question 2: What is the impact of deregulation on university staff?

Table 2. Impact of deregulation on the university staff

\begin{tabular}{llcccc}
\hline S/N & \multicolumn{1}{c}{ Statement } & $\begin{array}{c}\text { Agree } \\
\text { Frequency }\end{array}$ & \multicolumn{2}{c}{$\begin{array}{c}\text { Disagree } \\
\text { Frequency }\end{array}$} & $\%$ \\
\hline 1. & Managerial effectiveness and efficiency & 607 & 87 & 93 & 13 \\
2. & Managerial accountability & 600 & 86 & 100 & 14 \\
3. & Staff development & 354 & 51 & 346 & 49 \\
4. & Job security & 34 & 5 & 666 & 95 \\
5. & Brain drain among staff & 70 & 10 & 630 & 90 \\
6. & Equality in staff salary structure & 70 & 10 & 630 & 90 \\
\hline
\end{tabular}

Table 2 shows that deregulation does not guarantee job security nor improves staff development and equity in salary structure but it contributed to managerial effectiveness, efficiency, and accountability.

Research Question 3: What is the impact of deregulation of higher institution on the students?

Table 3. Impact of deregulation on the students

\begin{tabular}{clcccc}
\hline S/N & \multicolumn{1}{c}{ Statement } & $\begin{array}{c}\text { Agree } \\
\text { Frequency }\end{array}$ & $\%$ & $\begin{array}{c}\text { Disagree } \\
\text { Frequency }\end{array}$ & $\%$ \\
\hline 1. & Access to higher education is difficult & 633 & 90 & 67 & 10 \\
2. & Wide range of admission & 637 & 91 & 63 & 9 \\
3. & Class structure among students & 665 & 95 & 35 & 5 \\
4. & Exploitation by the institutions & 672 & 96 & 28 & 4 \\
5. & Improved discipline among students & 595 & 85 & 105 & 15 \\
\hline
\end{tabular}

Table 3 shows that students were affected in the areas of access to higher education, class structure, admission choice and exploitation by the institutions. However, it gives room for improved discipline. Canadian Federation of Students' report (2003) stated that due to deregulation, access to higher education is difficult for students and Nigeria is no exception. Also, Salim (2004) reported that the astronomical rise of application forms and the absorption capacities of the universities are at variance with each other. Also, if the effects of increased fees and levies are not cushioned, it will lead to less access to higher education. 
Research Question 4: What is the impact of deregulation on funding of higher institutions?

Table 4: Impact of deregulation on funding of higher institutions

\begin{tabular}{|c|c|c|c|c|c|}
\hline$S / N$ & Statement & Adequate & $\%$ & Inadequate & $\%$ \\
\hline & & Frequency & & Frequency & \\
\hline 1. & Subvention from the government & 55 & 8 & 645 & 92 \\
\hline 2. & Internally generated revenue & 103 & 15 & 597 & 85 \\
\hline 3. & Facilities and instructional materials & 301 & 43 & 399 & 57 \\
\hline 4. & Information Technology and Communication gadgets & 265 & 38 & 435 & 62 \\
\hline 5. & Stakeholders support & 207 & 30 & 493 & 70 \\
\hline 6. & Research funding & 232 & 33 & 468 & 67 \\
\hline
\end{tabular}

Table 4 shows that deregulation is not improving the funding of higher institutions in Nigeria but rather it throws the institutions into dilemma of sourcing for fund. However, Kolawole (2012) disagreed with this finding in that evidence showed that there was enough fund in the universities if properly managed. However, Adebayo (2003) recommended that the education stakeholders (parents, alumni, lecturers, Non-Governmental Organizations) should give support to financing higher education.

\section{Conclusion}

Nigeria is currently witnessing a period when the availability of education and training is being increasingly demanded for, and when the cost of providing these has grown to hitherto unimagined levels. Coupled with deregulatory practices in countries the world over, deregulation of Nigeria's education, especially at the higher level, seems inevitable. However, education is and should be seen to be about values making its total deregulation improper. As such, Nigeria must have focus of how to educate her citizens, not for manpower development alone, but also socially, culturally and politically. Thus certain policies should be evolved on how to accommodate students, mobilize staff and resources, review curricula and instructional materials as well as meeting rising cost of university education.

\section{Recommendations}

Deregulation, which provides perhaps the major hope for school effectiveness must be concerned not with government handing off funding of universities but with curriculum innovation, accountability, effective management and academic integrity. However, increase in federal government budgetary allocation to university education is suggested and total reliance on public funding might be a strategy too remote to be pursed as a single public policy option for the running of Nigerian universities. The giant stride made by the government recently in revitalizing the universities infrastructure is commendable

It is therefore suggested that other sources of internally generated funds be pursued by each university administration. Such sources could include investments such as consultancy services, guest houses, internet cafes, renting of built-up shops, spaces and recreational facilities, transportation services, and alumni donations. Other sources include donations by the friends of the university, putting universities research report and findings on the internet for sale, and collaborative curriculum and research efforts with national and international organizations. Nigerian universities should take advantage of the on-going academic globalization to improve standards to international levels as well as generate foreign exchange earnings. Besides the federal government, the roles of the other two tiers of government namely the state and the local, and other stakeholder such as parents, alumni associations, and business organizations, in funding university education, also need to be specified.

To complement government efforts, private individuals and organization universities should be expanded and better equipped. University autonomy as another form of deregulation should take up the challenge of adequate provision of university education to qualified and wiling Nigerian citizens. With an absorptive capacity of only $16.25 \%$ by the existing 128 Nigerian universities, more private involvement in university education is a welcome form of deregulation; provided quality and relevance are not compromised. To increase the access of the low-income group within the society who cannot afford the full payment at private universities, the public universities should be expanded and better equipped. Using management strategies at the institutional level, autonomy should emphasize improved standards in terms of improved curricula, and academic excellence by all and sundry within the system.

As important as fund generation is, education is about values, so the academic life should not be reduced purely to a money making venture. Rather, high academic standards and teacher quality in terms of professionalism should be pursued. To have the full gains of deregulation, climate of academic integrity should be enshrined in the operation of the university system. Under this climate, the five fundamental principles of honesty, trust, fairness, respect and responsibility should be promoted among all members of the academic community, for each other, for scholarship and research, and for the education process as a whole. 


\section{References}

Adebayo, F.A (2003). Towards effective financing higher education in Nigeria. Benin Journal of Educational Studies. University of Benin. 17(1):16-20.

Adeogun, A.A, Subair, S. T. \& Osifila, G.I. (2009). Deregulation of university education in Nigeria. Problems and prospects. Florida Journal of Educational Administration \& Policy. (3)1. Available: www.deregulation/ng (May5,2013)

Aina, Oladapo (2013). Ekiti State University 5-year strategies plan. Mimeograph.

Aladetoyinbo, Oluwabunmi \& Adeniyi, Bolaji C. (2012). University autonomy and administrative effectiveness in higher education in Nigeria. A seminar paper presented at Ekiti State University, Ado-Ekiti.

Canadian Federation of Students (2003). Deregulation: The sky is the limit for tuition fee. Available: www.deregulation/canada (July 6, 2013)

Castelan, A. (2004). Tuition deregulation may out students in the red. Available: www.deregulation/bc. Newsletters June 18, 2013.

Denise, Morgan (2002). Deregulating education in the United States: From vouchers to home schooling to the end of voluntary desegregation: Is the cost too high? Available: www.deregulation/usa. Newsfindlaw/commentary. June 6, 2013.

Ejiogu, (2002). Decentralization as panacea for Nigeria's education misadventure. A paper presented at the $6^{\text {th }}$ National conference of the National Association of Educational Researchers and Evaluators.

Kolawole Kemi (2012): Funding of higher education and governance in Ekiti State. A paper presented at HERPNET, Ibadan, Nigeria

Oyebade, S.A (2005). Privatization of university education in Nigeria: Implication for educational management. The Nigerian Association for Educational Administration and Planning (NAEAP).

Salim, B.A. (2004). Admission crisis in the Nigerian university system: The way forward. A convocational lecture at the University of Ilorin.

Tony, Freyer (2009): Deregulation theories in a litigious society. Cambridge Press. Online ISBN 9780511657504.482 571.

Tsai, C. (2001). The deregulation of higher education in Taiwan. Available: www.deregulation/ taiwan.newsletters. June 6, 2013

Ukeje, B.O. (2002). Financing education in Nigeria. The Nigerian Social Scientist. 5, (1), 31-39.

Uvah, I.I. (2003). Innovation and university management in the face of dwindling resources. Lecture presented to the Management of the University of Ilorin. 